\title{
'n Vertalende vakwoordeboek van politieke terme
}

\author{
Mariëtta Alberts, Leksikografie- en Terminologie-ontwikkeling, Pan-Suid- \\ Afrikaanse Taalraad, Pretoria, Republiek van Suid-Afrika \\ (marietta@pansalb.org.za)
}

Opsomming: Staatkundige en Verwante Terminologie wat in 1990 verskyn het, is aansienlik deur die Sentrum vir Politieke en Verwante Terminologie in Suider-Afrikaanse Tale (SEPTSA) hersien en bygewerk ten einde dit as die Nuwerwetse Politieke Woordeboek te publiseer. Die verskillende stadia in die hersiening en uitvoering van die projek word bespreek. Die hersiening bevat heelwat meer terme as die vorige publikasie en verskeie bylaes word ingesluit. Aandag word gegee aan die waarde van die tweetalige vertalende en die beplande meertalige verklarende politiekewetenskappeprojek binne die Suid-Afrikaanse en wêreldkonteks. Nuutskeppings en verskeie probleemterme word bespreek, spelling- en transliterasieprobleme wat by die verafrikaansing van ontleende terme ontstaan het, word behandel, en winste uit sowel die inheemse tale as uit vreemde tale word beskou. ' $n$ Oorsig word gegee van 'n verskeidenheid funksionele agtervoegsels wat baie produktief in die Nuwerwetse Politieke Woordeboek gebruik word. Die woordeboek bevat 'n aansienlike aantal afkortings vir volvorme. 'n Aanduiding word gegee van die soort afkortings wat in die woordeboek opgeneem is. Die bylaes bygevoeg by die woordeboek word bespreek, en die artikel sluit af met 'n oorsig oor toekomsplanne.

Sleutelwoorde: AFKORTING, AKRONIEM, MEERTALIGE VAKWOORDEBOEK, NUUTSKEPPING, PROBLEEMTERM, TERM, TERMINOLOGIE, TERMSKEPPING, TWEETALIGE TWEERIGTING VERTALENDE VAKWOORDEBOEK, TWEETALIGE VAKWOORDEBOEK, VERAFRIKAANSING, VERKLARENDE WOORDEBOEK, VERTALENDE WOORDEBOEK, VOLVORM

\begin{abstract}
A Translating Technical Dictionary of Political Terms. Political and Related Terminology that appeared in 1990 was revised and updated considerably by the Centre for Political and Related Terminology in Southern African Languages (CEPTSA) in order to publish it as the bilingual Modern Political Dictionary. The various stages of the revision and execution of the project are discussed. The revision contains many more terms than the previous publication and various annexures are included. The value of the bilingual translating and the envisaged multilingual explanatory political sciences project within South African and world context receives attention. Neologisms and several problem terms are discussed, spelling and transliteration problems that developed from the Afrikaansification of borrowed terms are treated, and gains from the indigenous languages as well as from foreign languages are surveyed. An overview is given of a variety of functional suffixes used productively in the Modern Political Dictionary. The dictionary contains quite a number of abbreviations for full forms. An indication is given of the type of abbreviations entered in the dictionary. The annexures added to the dictionary are discussed, and the article ends with an overview of future plans.
\end{abstract}

Lexikos 13 (AFRILEX-reeks/series 13: 2003): 271-286 
Keywords: ABBREVIATION, ACRONYM, AFRIKAANSIFICATION, BILINGUAL BIDIRECTIONAL TRANSLATING TECHNICAL DICTIONARY, BILINGUAL TECHNICAL DICTIONARY, EXPLANATORY DICTIONARY, FULL FORM, MULTILINGUAL TECHNICAL DICTIONARY, NEOLOGISM, PROBLEMATIC TERM, TERM, TERM CREATION, TERMINOLOGY, TRANSLATING DICTIONARY

\section{Inleiding}

Die ontwikkeling van internasionale staatkundige en politieke verhoudings gedurende die afgelope tien jaar asook die koms van demokrasie in Suid-Afrika het 'n groot toename in nuwe staatkundige en politieke terme tot gevolg gehad. Die bywerking en hersiening van Staatkundige en Verwante Terminologie wat in Januarie 1990 gepubliseer is, was dus noodsaaklik.

Taalgebruikers se kommunikasie- en leervaardighede en studente in die politieke en staatkundige wetenskappe kan baat vind by die tweetalige Nuwerwetse Politieke Woordeboek.

\subsection{Agtergrond van die vertalende vakwoordeboek van politieke terme}

Die vakwoordeboekprojek is in drie fases beplan. Die eerste fase was die publikasie van ' $n$ tweetalige tweerigting vertalende vakwoordeboek. Daarna sou die definiëringsfase volg. Fase 2 was egter 'n hersieningsfase en die derde fase sal nou uit die definiëring en verskaffing van Afrikataalekwivalente bestaan.

$$
\begin{aligned}
& \text { Fase 1: Vertalend } \Rightarrow \text { Fase 2: Hersiening } \Rightarrow \text { Fase 3: Verklarend } \\
& \text { (Tweetalig) (Tweetalig) (Meertalig) }
\end{aligned}
$$

Die hersiening van die bestaande vakwoordeboek was 'n grondliggende stap vir die volgende fase. Dit sal meebring dat 'n uitvoerige, bygewerkte vakwoordeboek tot stand kom waarvan die begrippe gedefinieer sal word voordat die Afrikataalekwivalente bygevoeg word ten einde 'n meertalige verklarende vakwoordeboek te publiseer.

\subsubsection{Fase 1: Ontstaan}

Gedurende 1983-84 is die behoefte aan 'n vakwoordeboek bepaal wat die politiek met sy verwante dissiplines dek. Die destydse Nasionale Terminologiediens (NTD) (tans Terminologiekoördineringsafdeling, Nasionale Taaldiens, Departement van Kuns en Kultuur) het daarop vakkundiges genader om aan die projek mee te werk en 'n Komitee vir Staatkundige en Verwante Terminologie is gevestig. Hierdie Komitee het van 1991 tot 1997 onder die NTD gefunksioneer. Toe die NTD en die eerste komiteelede die woordeboek begin beplan het, het hulle ooreengekom dat die komitee se eerste produk 'n tweetalige tweerigting vertalende vakwoordeboek sou wees. In fase 2 sou 'n opvolgpubli- 
kasie wat die politieke terme definieer, tot stand gebring word.

Die eerste fase is gedurende 1989 afgehandel en in Januarie 1990 is Staatkundige en Verwante Terminologie gepubliseer en amptelik vrygestel.

Die produk van fase 1 het die subgebiede staatsleer, internasionale politiek en staatsreg, publieke administrasie, munisipale regering en administrasie, Afrikapolitiek en ontwikkelingsadministrasie, en strategiese studies ingesluit. Die termkorpus het sowat 10000 terme (in sowel die Engels-Afrikaanse kant as die Afrikaans-Engelse kant) bevat. Benewens die NTD se taalkundige en terminografiese adviseurs het akademici verbonde aan universiteite en kundiges van die Kommissie vir Administrasie, Nasionale Intelligensiediens, Suid-Afrikaanse Polisie, Suid-Afrikaanse Weermag, Departement Buitelandse Sake, Departement Staatkundige Ontwikkeling en Beplanning, en die Afrika-Instituut, meegewerk.

\subsubsection{Fase 2: Hersiening}

Die dramatiese politieke omwenteling in Suid-Afrika het tot gevolg gehad dat baie beplanning op staatkundige terrein gedoen is om op nuwe beleid en strategieë te besluit ten einde nuwe staatkundige en politieke doelwitte te stel. Hierdie inisiatiewe het honderde nuwe staatkundige en politieke terme geskep.

Gedurende die finale redigering van die eerste uitgawe het die vakkomiteelede reeds met die tweede beplande fase, naamlik definiëring, begin. Ongelukkig het hierdie werk om verskeie redes stadig gevorder.

Die vakkundiges het van die begin af besef dat 'n verklarende termlys noodsaaklik is, maar dat die inhoud van die woordeboek van tyd tot tyd hersien sou moes word.

Ten tyde van die publikasie van die vakwoordeboek en die aanvang van fase 2 van die projek moes die vakkomitee oor die aanvanklike beplanning besin. Die behoefte aan 'n uitgebreide en hersiene uitgawe van Staatkundige en Verwante Terminologie het al hoe sterker geword. Die vakkomitee het derhalwe reeds in 1990 besluit om eers met die hersiening van die eerste woordeboek te begin voordat die terme gedefinieer sou word. Hierdie besluit is versterk deur die nuwe politieke bedeling wat tot 'n groot aantal nuwe terme aanleiding gegee het.

Die hersieningskomitee het die datakorpus van die eerste woordeboek nagenoeg verdriedubbel deur die bywerking van aanvullende terme en het ook die terme wat wel in die eerste woordeboek verskyn het, maar waarvan die fynere verskille ten opsigte van betekenis en nuanses nie genoegsaam ontrafel was nie, deeglik hersien. Die byvoeging van bylaes met inligting oor die parlemente van die wêreld en verwante instellings, intelligensie- en veiligheidsdienste van state, akronieme, e.s.m. is 'n stap wat die waarde van die nuwe publikasie aansienlik verhoog. Hierdie produk was teen die middel van 2002 persklaar en is in Desember 2002 gepubliseer.

Aan die einde van fase 2 is die eerste woordeboek dus wel aansienlik ver- 
beter, maar die behoefte aan die verklaring van tersaaklike terme is nog nie bevredig nie. Twee verdere behoeftes het na vore gekom, naamlik die ontwikkeling van vakkundige terminologie vir die Afrikatale, en die gevolglike vergemakliking van die studie van studente wat nie Engels of Afrikaans as moedertaal het nie. Hoewel 'n aantal terme uit die Afrikatale reeds in die tweede fase van die woordeboek opgeneem is, is dit nie voldoende om die nuwe behoefte te bevredig nie en is dit noodsaaklik dat die huidige woordeboek tydens 'n derde fase verder ontwikkel word.

\subsubsection{Fase 3: Meertalige verklarende woordeboek}

Navorsing wat deur die Terminologiekoördineringsafdeling, Nasionale Taaldiens, Departement van Kuns en Kultuur gedoen is, toon 'n duidelike behoefte aan 'n verklarende woordeboek wat ook die Afrikatale insluit. ' $n$ Snelgroeiende getal studente wat nie Engels as moedertaal het nie, studeer in vakrigtings wat deur hierdie pasverskene woordeboek gedek word. Dit is alreeds moeilik om in 'n tweede taal te studeer en die probleem word vererger deur die tegniese ingewikkeldheid van baie begrippe op hierdie terrein, wat nie deur die gewone woordeboeke ondervang word nie. Ook parlementariërs, vertalers binne en buite die staatsdiens, en skrywers in die media sal besondere baat vind by so ' $n$ produk. Voorts sal dit daadwerklik tot die uitbou van die Afrikatale bydra en terselfdertyd die Afrikaanse vaktaal bevorder.

Die Regering het homself daartoe verbind om die taalregte van alle SuidAfrikaanse burgers te beskerm. Die land het tans elf amptelike tale wat regmatige behandeling moet ontvang. Indien daar gepoog moet word om die ongelykhede van die verlede uit die weg te ruim, sal duidelike doelwitte gestel moet word vir taalontwikkeling in Suid-Afrika en stategieë sal bedink moet word om die Regering se doelwit van taalgelykheid te bereik.

Een van die plekke waar taalontwikkeling tot sy reg kan kom, is in die onderwyssituasie. As skoliere en studente begrippe in hul onderskeie eerste tale kan bemeester, sal hul eindresultate ook aansienlik beter wees. Nie alleen behoort die standaard van onderwys in Engels as medium van onderrig te verbeter nie, maar die ander amptelike tale behoort ook gemoderniseer en ontwikkel te word om kragtige kommunikasie- en onderrigmiddele te word.

'n Ideale onderrigsituasie sal vereis dat die terminologie van verskillende vakgebiede in die onderskeie amptelike tale beskikbaar moet wees. Meertalige verklarende vakwoordeboeke kan meehelp om die terminologie van bepaalde vakgebiede te verklaar en die leerproses aan te help.

Omdat daar egter 'n tekort aan vakkundiges bestaan wat tegelyk oor die vereiste taalkennis en kennis van die onderskeie subgebiede beskik, is dit nodig dat omskrywings of definisies van sleutelterme in Engels en Afrikaans geformuleer word om as grondslag te dien vir die vakkundig korrekte en aanvaarbare ekwivalent of omskrywing van die terme in die betrokke Afrikatale.

Fase 3 vereis dat die huidige werkspan uitgebrei word deur die byvoeging 
van kundiges met van die Afrikatale as eerste taal. Daarna sal die huidige datakorpus waarskynlik ook aangepas moet word om begrippe wat eie is aan die Afrikakultuur by te voeg. Die huidige datakorpus sal uitgebrei word om vir die bykomende doeltaalekwivalente voorsiening te maak.

Die terme in die databasiskorpus is op MultiTerm ingevoer in databasisformaat. Dit impliseer dat selfs navorsingsnotas wat nie normaalweg in ' $n$ vakwoordeboek verskyn nie, ook opgeteken is. Die terme maak ook deel uit van die Nasionale Termbank van die Nasionale Taaldiens, Departement van Kuns en Kultuur.

Die loodsondersoek wat reeds gedoen is, bevestig die behoefte aan so ' $n$ meertalige verklarende vakwoordeboek. Dit toon ook dat die projek uitvoerbaar is. Daar is egter ' $n$ belangrike faktor wat nie uit die oog verloor moet word nie, naamlik dat die huidige werkspan nie oor genoegsame fondse beskik om die verdere ontwikkelingsfases van die projek te finansier nie.

\subsection{Sentrum vir Politieke en Verwante Terminologie in Suider-Afrikaanse Tale (SEPTSA)}

Die Komitee vir Staatkundige en Verwante Terminologie het as gevolg van die staking van staatsteun in 1997 besluit om 'n Sentrum vir Politieke en Verwante Terminologie in Suider-Afrikaanse Tale (SEPTSA) te stig ten einde die hersiene tweetalige woordeboek uit te gee, die meertalige woordeboek te produseer en ander professionele produkte te lewer. Die reglement van SEPTSA is op 27 November 1998 gefinaliseer. Dit funksioneer tans met die welwillende medewerking van die Randse Afrikaanse Universiteit en is in sy Departement Politieke en Regeerkunde gevestig. SEPTSA word dus met behulp van 'n grondwet wat deur die Universiteitsraad goedgekeur is, bestuur en met ' $n$ sakeplan bedryf.

Die medewerkers van SEPTSA poog om fondse vir woordeboekprojekte op ' $n$ verantwoordelike wyse te bekom, aan te wend en te administreer. Prolingua se finansiële steun van 1999 tot 2000 het dit moontlik gemaak om met die werk voort te gaan. SEPTSA het vroeg in 2001 en in 2002 fondse van die Taalsekretariaat ontvang wat gesorg het vir die voltooiing van die projek. Die Randse Afrikaanse Universiteit het in 2002 'n bydrae gemaak sodat die woordeboek gepubliseer kon word.

\section{Politieke terminologie in die vertalende vakwoordeboek}

Die volgende vakgebiede word in die Nuwerwetse Politieke Woordeboek verteenwoordig: politieke wetenskappe, publieke administrasie en regeerkunde, internasionale verhoudinge, ontwikkelingstudies en strategiese studies. Terme is wyd geëkserpeer, nie slegs uit vakkundige bronne nie, maar ook uit populêre bronne soos tydskrifte en koerante. Die Komiteelede moes op grond van hul eie kennis, aanvoeling en inligting uit verwante bronne besluite neem oor die 
omvang en vakgebiedgrense van die woordeboek, met die toepaslikheid van elke term vir hierdie woordeboek as riglyn.

\subsection{Nuutskeppings}

SEPTSA het met baie interessante terme te doen gekry wat van termekwivalente voorsien moes word. Dit het dan ook vir 'n paar goeie nuutskeppinge in Afrikaans gesorg wat in die Nuwerwetse Politieke Woordeboek verskyn:

\section{brain gain: kundigheidswins}

brain train: kundigheidsopleiding

clout: klapkrag (spierkrag)

constituency (voter's district): kiesafdeling (kiesdistrik)

constituency: kiesergevolg

crony: kornuit

cronyism: kornuitbegunstiging

entryism Ipractice of infiltrating a political party in order to influence that party's policy from within\}: politieke binnedringing \{praktyk om ' $n$ politieke party te infiltreer ten einde daardie party se beleid van binne af te beïnoloed\}

fat cat: roomvraat (geiljan, vetkat $<$ af te keur $>$ )

gangsterism: rampokkery

gender: gender

gutter education: flenteronderwys (afskeeponderwys)

impeach: ampsaanklag instel teen

impeachment \{charge against incumbent of a specific office\}: ampsaanklag \{aanklag teen bekleër van ' $n$ bepaalde amp\}

impeachement: staat van aanklag

kickback: gunsloon

lumpenproletariat \{in the Marxist theory\}: flenterbroekproletariaat \{in die Marxistiese teorie\} (lumpenproletariaat)

periphery doctrine \{Israeli foreign policy\}: randdoktrine \{Israelse buitelandse beleid\}

shamocracy: foppokrasie (skyndemokrasie)

\subsection{Probleemterme}

Daar is verskeie brontaalterme wat probleme skep wanneer hulle van vertaalekwivalente voorsien moet word. In sommige gevalle is die terme bloot net nie vertaalbaar nie omdat bepaalde emotiewe waardes wat reeds in die brontaal aan die terme gekoppel word, in die vertaalproses verlore gaan. In ander gevalle bestaan daar reeds vertaalekwivalente wat nie dieselfde betekeniswaarde van die terme in die brontaal weergee nie. Voorbeelde hiervan wat in die $\mathrm{Nu}$ werwetse Politieke Woordeboek opgeneem is, is die volgende:

civics $\Rightarrow$ civic associations ${ }^{1}$

civic association: burgervereniging

civic associations (civics): civics 
dumping \{eg of radioactive waste\}: storting \{bv van radio-aktiewe afval\} dumping \{eg of economic goods\}: dumping \{bv van ekonomiese goedere\}

struggle: stryd

struggle <the struggle> in South Africa it refers to the period ca 1960-1990 in which the black freedom movement conducted a violent revolutionary struggle against the NP government\}: struggle < die struggle> \{in Suid-Afrika verwys dit na die tydperk ca 1960-1990 waarin swart bevrydingsbewegings 'n gewelddadige rewolusionêre stryd teen die NP-regering gevoer het

township \{a black residential area, mainly associated with apartheid\}: township \{'n swart woongebied, hoofsaaklik verbind met apartheid\}

township: lokasie

township: woonbuurt

township \{term denoting various forms of residential areas in other states such as US, Canada and UK\}: dorpsgebied \{term wat verskeie vorme van woongebiede in ander state soos die VSA, Kanada en VK aandui\}

\subsection{Spelling- en transliterasieprobleme}

In sekere gevalle waar daar onduidelikheid bestaan het oor die spelling van die brontaalterme, het SEPTSA seker gemaak dat die korrekte spelwyse opgeneem word, veral by terme van vreemde herkoms. Die oorspronklike taal se spelling en uitspraak is ook met die betrokke ambassades uitgeklaar. Die Afrikaanse Woordelys en Spelreëls (AWS) is geraadpleeg wanneer terme van vreemde herkoms 'n verafrikaanste termekwivalent gekry het. Indien die AWS nie genoegsame leiding kon verskaf nie, is die Taalkommissie geraadpleeg.

SEPTSA het baie moeite gedoen om die regte uitspraak van terme te bekom en om dan tydens die transliterasieproses seker te maak dat die uitspraak nie tydens die verafrikaansing daarvan verlore gaan nie. Die navorsingsnotas by die winste uit vreemde tale dui op die besondere sorg waarmee die transliterasieproses hanteer is, bv. by Hasidim en mukhtar:

Hasidim <Hebrew; pl of Hasid> \{ultra-orthodox Jewish sect\}: Gasidim \{ultra-ortodokse Joodse sekte\} Navorsingsnota: Collins gee die Hebreeuse uitspraak as xasidim; Webster gee: hasid/chasid, hassid/chassid pl. hasidim/hassidim - one who is pious. Bosman, Van der Merwe en Hiemstra verwys van Has(s)idism na Chas(s)idism en gee as Afrikaanse ekwivalent Chassidisme. Die Komitee moet versigtig wees wat die verafrikaansing betref en behoort minstens ook ander spelvorme toe te laat soos chasidim/chassidim. Hierdie tipe transliterasie is soortgelyk aan chaos, chemie, charisma. Gesprekke met kundiges en raadpleging van die AWS toon dat die sagte $g$ in Afrikaans meestal as $g$ geskryf word, maar dat ander vorme wel as ch, byvoorbeeld chemie, voorkom en reeds ingeburger is. Die geval behoort na die Taalkommissie verwys te word vir leiding.

mukhtar <Arabic> \{elected headman of a settlement\}: moegtar \{gekose hoofman van ' $n$ nedersetting\} Navorsingsnota: Op grond van ondervinding met die verafrikaansing van die Engelse vorm $-\boldsymbol{k} \boldsymbol{h}$ - soos in mukhtar, word daar aanbeveel 
dat die Komitee in Afrikaans moechtar skryf — dis die sagte $g$-klank soos in chemie. Die voorstel is dat dit minstens as wisselvorm opgeneem word en as voorkeurspelling vir Afrikaans aanvaar word. Die geval behoort na die Taalkommissie verwys te word vir leiding.

\subsubsection{Winste uit die inheemse tale}

Daar is etlike terme uit die inheemse tale wat reeds in Afrikaans ingeburger is. Voorbeelde hiervan is terme soos shebeen (Afr. sjebien), stokvel, spaza en spaza shop (Afr. spazawinkel).

Meer onlangse winste kan nog teruggevoer word na die oorspronklike tale. Voorbeelde hiervan wat ook die Afrikaanse vertalings toon, is die volgende:

(a) Zoeloe, bv. amabutho, amadlozi, imbizo, imbongi, impi, impimpi, indaba, induna, inkatha, umKhonto weSizwe, mukhuku, inkosi en Shenge.

amabutho <Zulu; pl of ibutho> \{peer group\}: amabutho <Zoeloe; mv van ibutho> \{portuurgroep\}

amabutho $<$ Zulu - pl of ibutho; incorrectly used by the media to refer to people in traditional gear purported to belong to Inkatha $>$ \{ a group of traditional warriors\}: amabutho <Zoeloe - mv van ibutho; word verkeerdelik deur die media gebruik om na mense in tradisionele drag as behorende tot Inkatha te verwys $>$ \{'n groep tradisionele krygers\}

amadlozi $<$ Zulu $>$ \{spirits of the forefathers\}: amadlozi $<$ Zoeloe $>$ \{voorvadergeeste\}

imbizo $<$ Zulu $>$ a gathering called by the traditional leader of a nation to discuss serious or important issues pertaining to the nation\}: imbizo $<$ Zoeloe $>\{$ ' $n$ vergadering byeengeroep deur ' $n$ tradisionele leier van 'n nasie om ernstige of belangrike kwessies wat die nasie raak, te bespreek\}

impi $<$ Zulu $>$ : impi $<$ Zoeloe $>^{2}$

indaba $<Z$ Zulu $>\{$ a serious business to be discussed $\}$ : indaba $<$ Zoeloe $>$ \{'n belangrike saak wat bespreek moet word\}

induna $<Z u l u>$ the traditional counsellor of a ruler or king appointed because of his allegiance and who sometimes manages certain of the affairs of the ruler or king): indoena $<$ Zoeloe> \{die tradisionele raadgewer van 'n heerser of koning weens sy trou en wat soms sekere sake van die heerser of koning behartig\}

(b) Sotho, bv. difaqane en lekgotla.

difaqane $<$ Sotho $>$ \{displacement of population caused by wars - eg those by Shaka\} (mfecane $<$ Nguni $>$ ): bevolkingsverplasing \{bevolkingsverplasing agv oorloë - bv dié deur Shaka ${ }^{3}$

lekgotla $<$ Sotho $>$ \{eg court where men sit; troop of warriors $\}$ : lekgotla $<$ Sotho $>$ \{bv hof waar mans sit; troep krygers\}

(c) Setswana, bv. Kgosi.

Kgosi <pl diKgosi; Setswana $>$ \{leader of a group in Tswana communities\}: Kgosi $<\mathrm{mv}$ diKgosi; Setswana> \{leier van 'n groep in Tswana-gemeenskappe\} 


\subsubsection{Winste uit Afrikaans}

Dié terme, bv. apartheid, Hanskakie, heemraad, kraal, kragdadig, verkramp, verlig, Vierkleur, volkskapitalisme, volkskool en volkstaat is onveranderd in Engels oorgeneem.

apartheid iformer policy of institutionalised separation of or discrimination between races in South Africa): apartheid \{voormalige beleid van geïnstitusionaliseerde skeiding van of diskriminasie tussen rasse in Suid-Afrika\}

kragdadig <Afrikaans - compare forceful > iwith reference to forceful politics; orginated with John Vorster): kragdadig (met verwysing na kragdadige politiek; begin met John Vorster\}

verkramp \{highly conservative in politics; originated in RSA\}: verkramp \{hoogs konserwatief in politiek; oorsprong in RSA\}

verlig \{liberal in politics; originated in RSA\}: verlig \{liberaal in politiek; oorsprong in $R S A\}$

\subsubsection{Winste uit vreemde tale}

Behalwe terme soos Great Society, Green Berets, green card, Ku Klux Klan en marine uit Amerikaans, gentleman en Master of the House uit Engels, grundgesetz, länder citizenship, Luftwaffe, reichskanzler en stiftung uit Duits en gendarmerie, laisser-aller, laisser-faire en laissez-passer uit Frans, is dit terme uit veral die Oosterse tale wat in Nuwerwetse Politieke Woordeboek opval. Ontlenings aan die volgende tale kan met enkele voorbeelde wat ook die Afrikaanse vertalings toon, vermeld word:

(a) Arabies, bv. fedayeen, Hizbollah, jihad, jamhuriyah, mukhtar en wazir.

fedayeen $<\mathrm{pl}$; Arabic $>$ \{Muslim commando force, especially one operating against Israel\}: fedajien \{Moslem-kommandomag, veral een wat teen Israel optree\}

jihad \{holy Islamic struggle\}: djehad <meer korrekte vorm in Afrikaans> \{heilige Islamitiese stryd\} (djihad, jihad) ${ }^{4}$

jamhuriyah <Arabic> \{republic, sometimes people's republic\} (jumhúriyah): djomhoerija \{republiek, soms volksrepubliek\}

wazir $<$ Arabic $>$ \{minister\}: visier $\{$ minister $\}$

(b) Hebreeus, bv. Haganah, Hasidim, Histadrut, Mifliget Po'alei Eretz Yisrael en moshav.

Haganah $<$ Hebrew $>$ \{Israeli pre-state underground army\}: Hagana \{Israelse voorstaatse ondergrondse leër\}

moshav $<$ Hebrew; sing of moshavim $>$ \{cooperative settlement in Israel, consisting of a number of small farms\}: mosjav \{koöperatiewe nedersetting in Israel wat uit ' $n$ groepie klein plasies bestaan\}

(c) Indiese tale, bv. Kshatriya, Lok Sabha, kuchitollah, pariah, raj, raja, Rajya Sabha, Sudra, suttee, Vaisya en varna.

Kshatriya <Indian languages> the second of the four main Hindu varna, the warrior 
caste\}: Tsjatrija \{die tweede kaste van die vier hoof Hindoe-warne, die krygerkaste\} raj <Indian languages $>$ \{rule, especially in India\}: radj \{heerskappy, veral in Indië\}

Sudra <Indian languages> \{lowest of the four main Hindu varna, the workers\}: Sjoedre \{die laagste van die vier hoof Hindoe-warne, die werkers\}

suttee <Indian languages> \{former custom of widow burning in India\}: sati \{voormalige gewoonte van weduweeverbranding in Indië\}

Vaisya <Indian languages> \{the third of the four main Hindu varna, the traders\}: Waisje \{die derde van die vier hoof Hindoe-warne, die handelaars\}

varna <Indian languages> the degree of pureness determining a caste\}: warne \{graad van reinheid wat ' $n$ kaste bepaal\}

(d) Indonesies, bv. keterbukaan.

keterbukaan <Indonesian> \{openness - Indonesian political policy\}: kieterboekaan \{openheid - Indonesiese politieke beleid\}

(e) Iraans, bv. bandbazi, grand ayatollah, jasus-khane en velayet-e faqih.

jasus-khane <Iranian> (house of spies) \{with reference to the American embassy in Tehran\}: jasoes-gane \{met verwysing na die Amerikaanse ambassade in Teheran\} (huis van spioene)

velayet-e faqih <Iranian> \{governance by Islamic jurisprudence\}: welajet-e fakieh \{regering volgens Islamitiese regsleer\}

(f) Japannees, bv. chuzaisho, daimyo, Domei, genro, habatsu, Heisei, ie, kaisha, kaizen, kamikaze, kanban, Keidanren, keiretsu, Keizai Dóyukai, kinken seiji, ko, koenkai, Kokkai, Meiji, mikado, Nikkeiren, ringi, samurai, Sei-i Tai Shogun, shogun, shogunate, Sho Wa, Sohyo, yakuza, zaibatsu en zaikai.

daimyo <Japanese $>$ \{feudal lords in shogunate\}: daimijô \{feodale lords in sjoghoenaat\}

Domei <Japanese> \{private sector labour union confederation\}: Domê <Japannees> \{vakbondfederasie van die privaatsektor $\}^{5}$

genro < Japanese $>$ \{elder statesmen\}: ghenrô $\{\text { ringkopstaatsmanne }\}^{6}$

Heisei <Japanese> (era of universal peace) \{title of the reign of emperor Akihito\}: Heisei <Japannees> \{titel van die bewind van keiser Akihito\} (tydvak van universele vrede)

ie <Japanese> \{Japanese household; building block of the feudal Japanese political system\}: ijee \{Japannese huishouding; bousteen van die feodale Japannese politieke stelsel\}

kamikaze <Japanese> \{literally divine wind blowing away the enemy; generally refers to suicidal military operations\}: kamikazê \{letterlik goddelike wind wat die vyand wegwaai; verwys gewoonlik na selfmoord militêre operasies\}

Keidanren <Japanese $>$ \{federation of industrial and trading organisations\}: Kêdanren \{federasie van nywerheids- en handelsorganisasies\}

koenkai <Japanese > \{informal campaign organisers and supporters for local politicians\}: kôênkai \{informele veldtogorganiseerders en ondersteuners van plaaslike politici\}

mikado <Japanese> \{title foreigners use for the Japanese emperor\}: mikadô \{titel wat buitelanders vir die Japannese keiser gebruik\}

ringi $<$ Japanese $>$ \{consensus\}: ringhie $\{$ konsensus\}

samurai <Japanese $>$ \{warrior caste in feudal Japan\}: samoeraai $\{k r y g s k a s t e$ in feodale 
Japan\}

shogun <Japanese $>$ \{emperor's chief general and de facto ruler; specific mandate of emperor\}: sjoghoen \{keiser se oppergeneraal en de facto heerser; bepaalde mandaat van keiser\}

(g) Koreaans, bv. chaebol en juche.

chaebol <Korean> \{government-promoted dominant business conglomerate\}: tjêbil \{oorheersende sakekonglomeraat wat deur die regering bevorder word\}

juche $<$ Korean $>$ \{autarchical political economic policy of North Korea\}: joetje $<$ Koreaans $>$ \{outargiese politieke ekonomiese beleid van Noord-Korea\}

(h) Sjinees, bv. ganbu en Kuo-miin ta-hui.

ganbu <Chinese> \{leading bureaucrats in the People's Republic of China\}: ghanboe \{vooraanstaande burokrate in die Volksrepubliek Sjina\}

Kuo-min ta-hui $<$ Chinese $>$ \{National Assembly; amends constitution, formerly used to elect president\}: Gwo-min ta-hê (Nasionale Vergadering; wysig grondwet, voorheen gebruik om president te kies\}

(i) Turks, bv. ulema.

ulema $<$ Turkish $>$ \{Muslim scholars\} (ulama $<$ Arabic $>$ ): oelema $\{$ Moslemgeleerdes $\}$

\subsection{Funksionele agtervoegsels}

Dit blyk dat daar veral sekere agtervoegsels is wat baie funksioneel in Nuwerwetse Politieke Woordeboek optree:

(a) -acy, bv. in conspiracy, diplomacy, efficacy, fallacy, literacy, papacy en supremacy. Behalwe diplomacy word nie een van dié terme in Afrikaans met -asie-vorme vertaal nie. Dié agtervoegsel is dus nie ook met sy Afrikaanse ekwivalent gelemmatiseer nie.

(b) -archy, bv. in anarchy, autarchy, callarchy, diarchy, monarchy, oligarchy en patriarchy. Al dié terme word ook in Afrikaans vertaal met die gebruikmaking van die agtervoegsel -argie. Dié agtervoegsel is dus soos volg gelemmatiseer:

-archy \{rule by\}: -argie \{heerskappy deur\}

(c) -cracy, bv. in aristocracy, autocracy, bureaucracy, democracy, ergotocracy, gerontocracy, hagiocracy, hierocracy, isocracy, kakistocracy, nomocracy, ochlocracy, plutocracy, shamocracy, technocracy en theocracy. Al dié terme word in Afrikaans met -krasie-vorme vertaal. Dié agtervoegsel is dus soos volg opgeneem:

-cracy \{exercise of power by\}: -krasie \{uitoefening van mag deur\}

Die definisie is egter te beperk, want dit dek nie die volledige spektrum van betekenisse wat dié agtervoegsel kan hê nie: "'n vorm van regering", 
" 'n politieke of sosiale klas", of " 'n sosiale of politieke teorie" (vgl. Urdang 1982: 257).

(d) -ism, bv. in communism, dualism, elitism, fanaticism, globalism, holism, en ook in gevalle wat van eiename afgelei is soos Chartism, Confucianism, Fascism, Gaullism, Hertzogism. Dit is vreemd dat dié agtervoegsel en die Afrikaanse vorm -isme wat albei 'n aansienlike gebruiksfrekwensie het, nie apart gelemmatiseer is nie. In die politiek het dit veral drie betekenisse: " 'n handeling of gebruik", " 'n gesteldheid of toestand", en "beginsels, leerstellings of opvattings, of 'n organisasie gestig om hulle te ondersteun" (vgl. Urdang 1982: 203).

\subsection{Afkortings}

Die Nuwerwetse Politieke Woordeboek bevat 'n groot aantal afkortings vir verskeie volvorme. Die volvorm en afkorting word albei opgeneem en die afkorting kruisverwys na die volvorm. Voorbeelde:

(a) Letterafkortings

$\mathbf{A A M} \Rightarrow$ air to air missile air to air missile (AAM): lug-na-lug-missiel (LLM, lug-tot-lug-missiel)

$\mathbf{A A M} \Rightarrow$ Anti-Apartheid Movement

Anti-Apartheid Movement (AAM): Anti-Apartheidsbeweging (AAB)

(b) Akronieme

COSATU $\Rightarrow$ Congress of South African Trade Unions

Congress of South African Trade Unions (COSATU): Congress of South African Trade Unions (COSATU)

ECOMOG $\Rightarrow$ ECOWAS Monitoring Group

ECOWAS Monitoring Group \{military grouping of ECOWAS\} (ECOMOG): EGWAS Moniteringsgroep \{militêre groepering van ECOWAS\} (EGMOG)

GEAR $\Rightarrow$ Growth, Employment and Redistribution Strategy

Growth, Employment and Redistribution Strategy (GEAR): Strategie vir Groei, Werkverskaffing en Herverdeling (GEAR)

\subsection{Bylaes}

Die woordeboek word afgesluit deur ' $n$ agtal tweetalige bylaes wat ' $n$ aantal terme alfabeties of tabellaries bymekaargroepeer vir vinnige en (of) oorsigtelike naslaandoeleindes.

(a) Die eerste bylae bevat akronieme en afkortings gevolg deur hul volvorme. Al die inskrywings in dié bylae is ook in die hooflys op hul alfabetiese plekke opgeneem waar hulle na die volvorme verwys word wat ook in die hooflys voorkom. 
(b) Die tweede bylae gee die parlemente van die wêreld in ' $n$ tabel bestaande uit vier kolomme: die name van die state in die eerste kolom, dié van die parlemente in die tweede kolom en, waar parlemente twee kamers het, die kamers in die derde en vierde kolomme. Die tabel is alfabeties gerangskik volgens die algemene name van die state in Engels, gevolg deur die formele name van die state, wat op hul beurt weer deur die name van die state in hul oorspronklike tale gevolg word.

(c) Die terme in die derde bylae wat adellike titels en ampte bevat, is ook alfabeties as lemmas in die hooflys opgeneem. Dié bylae is van groot nut vir die woordeboekgebruiker wat die Afrikaanse ekwivalente vir die vreemde benamings benodig of vir die oningeligte vir wie die verskil tussen verskillende benamings nie altyd duidelik is nie. Die volgende sal onder andere daar aangetref word: prince consort (Afr. prinsgemaal), prince regent (Afr. prins-regent), prince royal (Afr. vorsteprins), queen consort (Afr. koningsgemalin), queen dowager (Afr. koninginweduwee), queen regent (Afr. koninginregentes), queen regnant (Afr. regerende koningin).

(d) In die vierde bylae word klassieke Latynse en Griekse terme wat ook in die hooflys opgeneem is, gerieflik saamgevat.

(e) Die terminologie ten opsigte van ministeriële en administratiewe ampte in die Verenigde Koninkryk en die Verenigde State van Amerika verskil aansienlik van dié in Suid-Afrika. Al dié terme wat ook alfabeties in die hooflys van die woordeboek opgeneem is, word in die vyfde bylae hiërargies met hul vertalings aangebied. Dié oorsigtelike aanbieding wat ook vergelykings tussen die ampte van die verskillende lande moontlik maak, verskaf onontbeerlike hulp, ook ten opsigte van korrekte vertalings.

(f) Die sesde bylae bevat tipiese militêre range. Waar dié terme as lemmas in die hooflys opgeneem is, word hulle met kleinletters geskryf. In hierdie hiërargiese lys waar die rangbenaminge met hul afkortings onder die hoofde "Leër/Lugmag" en "Vloot" gerangskik is, word hulle met hoofletters geskryf. Die notas wat op hierdie tabel volg en onder andere inligting oor aanspreekvorme verskaf, is van groot gebruikswaarde.

(g) Gegewens oor inligtings- en veiligheidsdienste word in tabelvorm in die sewende bylae verskaf: in die eerste kolom word die name van die state vermeld; in die tweede kolom volg die afkortings van die dienste; die derde kolom wat die volvorme van die afkortings verskaf, is in drie afdelings verdeel: eers word die name in die oorspronklike tale gegee, daarna in Engels en Afrikaans, en, in die vierde kolom, volg opmerkings oor die aard van die dienste. Die afkortings is nie ook, soos die terme in die ander bylaes, alfabeties in die hooflys opgeneem nie. Dié tabel verskaf 'n maklik raadpleegbare oorsig van moeilik bekombare inligting. 
(h) In die agste bylae verskyn byname van politieke persoonlikhede. Die volgende sal onder andere daar gevind word: Groot Krokodil (skeldnaam vir die voormalige Suid-Afrikaanse staatspresident P.W. Botha), Iron Lady (Afr. Ystervrou) (naam gebruik vir die voormalige Britse eerste minister Margaret Thatcher), Jimmy the peanut farmer (Jimmy the peanut king) (Afr. Jimmy die grondboontjieboer (Jimmy die grondboontjiekoning)) (skeldnaamverwysing na Jimmy Carter, president van die V.S.A., 1977-1981), Kortbroek (naam gebruik vir Marthinus van Schalkwyk, leier van die Nuwe Nasionale Party, 1996-), Mother of the Nation (Afr. Moeder van die Nasie) (naam gebruik vir Winnie Madikizela-Mandela).

\section{Slotsom}

Die resultate van die navorsing wat reeds gedoen is, die taalverryking wat plaasgevind het, ontlenings uit vreemde en inheemse tale, die navorsing wat reeds ten grondslag van die meertalige verklarende uitgawe aan die gang is en die totstandbrenging van 'n unieke produk waarby die vakgebied soveel sal baat, is van onskatbare waarde.

Die vakkomitee wat die hersiene en bygewerkte uitgawe van die woordeboek so vinnig ná die vorige woordeboek die lig laat sien het, kan met reg trots wees op die eindproduk. Die Nuwerwetse Politieke Woordeboek is in werklikheid 'n heeltemal nuwe woordeboek as ' $n$ mens in aanmerking neem dat die sowat 5000 brontaalterme na 16000 vermeerder is, en dat uitgebreide verklarende voorstukke, verbandsverklarings, transliterasies en bylaes bygekom het.

Die woordeboek bied velerlei gebruiks- en toepassingsmoontlikhede. Dit is ' $n$ bruikbare vakwoordeboek wat met groot vrug deur taalpraktisyns geraadpleeg kan word en deur hulle aangeskaf behoort te word.

Vertalers en redigeerders sal hierdie vakwoordeboek om verskeie redes nuttig vind. Tony Moen, 'n bedrewe vertaler en redigeerder, noem die volgende as belangrike redes waarom vertalers en redigeerders dié vakwoordeboek behoort te gebruik:

- alle inskrywings is volledig tweetalig, so ook alle aantekeninge, definisies en kontekstuele inligting;

- die datakorpus bevat resente inligting;

- die lys bevat allerlei bruikbare nuutskeppings; en

- dit bied ' $n$ breë oorsig van die vakgebied, insluitend terme wat uitgelaat sou kon word vanweë hul spesifieke militêre of ekonomiese aard.

Sowel die tweetalige vertalende woordeboek as die beplande meertalige woordeboek behoort ' $n$ besondere rol in die vakterrein te speel. Dit behels:

- die aanvulling en verryking van die Afrikaanse vaktaal, en die gebruik 
en standaardisering van die Afrikaanse terme;

- die lewering van ' $n$ betekenisvolle bydrae tot die vergemakliking van die leerproses vir duisende studente wat nie Engels as moedertaal het nie ook in sommige van Suid-Afrika se buurstate;

- die instaatstelling van parlementariërs en ander openbare figure tot korrekte taalgebruik;

- die vergemakliking van vertalings binne die staatsdiens;

- die bevordering van die korrekte gebruik van begrippe en taal in die media;

- die daadwerklike uitbouing van die "agtergeblewe" tale en die speel van 'n positiewe bemagtigingsrol; en

- die benutting deur ander lede van die Dietse taalgroep.

Die Engelse gedeelte sou ook geredelik op sy eie gepubliseer kon word om 'n goeie verkoper in Engelstalige lande te word.

Ten einde werk aan die derde fase van die vakwoordeboek, naamlik die definiëring en verskaffing van die Afrikatale te bespoedig, moet ander uitweë vir befondsing as die huidige bedeling gevind word. Dit is noodsaaklik dat die werk aan die meertalige projek vinniger vorder. Die vaktaalgemeenskap sien met groot verwagting uit na hierdie meertalige verklarende woordeboek wat deur SEPTSA beoog word.

\section{Aantekeninge}

1. Aanvanklik is die meer formele civic association gebruik, maar later is oorgeslaan na civics.

2. Die term beteken letterlik "oorlog", maar kan ook gebruik word om na amabutho (portuurgroep) te verwys.

3. Die Sothowoord is difaqane, en die Nguniwoord mfecane wat, indien hulle letterlik vertaal word, "verdelgingsoorloë" beteken. Groot groepe mense het met hul families en besittings voor ander groepe uitgevlug wat hulle wou uitwis, en in dié proses het hulle self ook ander groepe aangeval. Die Engelse en Afrikaanse ekwivalente verwys dus streng gesproke eintlik na die resultaat van die volksverdelging.

4. Die WAT gee: djihâd (Arab.) Heilige oorlog van die Mohammedane teen ongelowiges en ketters, soos deur die Koran voorgeskryf. In die konteks van die staatkunde is dit nie soseer ' $n$ oorlog nie, maar eerder 'n stryd. Die $d j$-klank in Arabies behoort hier uitgespreek te word. Vgl. bv. Engels Jakarta wat in Afrikaans Djakarta word. Die 1994-uitgawe van die HAT gee net djihad as verafrikaanste vorm aan, maar navorsing deur die Komitee toon dat die vorm jihad ook vir die ekwivalensie behou behoort te word omdat dit al, veral onder studente, inslag gevind het.

5. Die Japannese ei word in sommige woorde as /əi/ en in ander as / $/ \varepsilon /$ uitgespreek - vandaar die tweeledige transliterasie in Afrikaans, vgl. Heisei, Kêdanren.

6. Die Komitee het besluit om wel die r-skryfwyse te behou, hoewel die Japannese die / $\mathrm{\varepsilon r} /$ as /عl/ uitspreek, vgl. Kêdanren, ringhie. 


\section{Verwysings}

Bosman, D.B., I.W. van der Merwe en L.W. Hiemstra. 1984. Tweetalige Woordeboek/Bilingual Dictionary. Kaapstad: Tafelberg.

Committee for Political and Related Terminology / Komitee vir Staatkundige en Verwante Terminologie. 2002. Modern Political Dictionary: Terms, Concepts and Usages in Politics and the Political Sciences/Nuwerwetse Politieke Woordeboek: Terme, begrippe en gebruike in die politiek en politieke wetenskappe. Johannesburg: Centre for Political and Related Terminology in Southern African Languages (CEPTSA), Rand Afrikaans University/Sentrum vir Politieke en Verwante Terminologie in Suider-Afrikaanse Tale (SEPTSA), Randse Afrikaanse Universiteit.

Gove, B.P. (Hoofred.). 19613. Webster's Third New International Dictionary of the English Language. Londen: G. Bell/Springfield, Mass.: G. \& C. Merriam.

Moen, Tony. 2003. SATI Award for Outstanding Translation. Ongepubliseerde dokument.

Odendal, F.F. et al. 19943. Verklarende Handwoordeboek van die Afrikaanse Taal. Midrand: Perskor.

Schoonees, P.C. (Hoofred.). 1956. Woordeboek van die Afrikaanse Taal. Tweede Deel: D-F. Pretoria: Die Staatsdrukker.

Taalkommissie van die Suid-Afrikaanse Akademie vir Wetenskap en Kuns. 20028. Afrikaanse Woordelys en Spelreëls. Kaapstad: Pharos.

Urdang, Laurence (Red. dir.). 1982. Suffixes and Other Word-Final Elements of English. Detroit: Gale Research Co. 